The International Journal Of Engineering And Science (IJES)

|| Volume || 6 || Issue || 1 || Pages || PP 33-39 || 2017 ||

ISSN (e): $2319-1813 \operatorname{ISSN}$ (p): $2319-1805$

\title{
A Detailed Analysis of Cotton Textile Industry at Bardhaman Cluster of West Bengal
}

\author{
Sharmistha Sarkar \\ Research Scholar, Department of Geography, University of Calcutta
}

\begin{abstract}
-
West Bengal had a great heritage of cotton textile industry from the very ancient period of time. This work was traditionally done by rural artisans, they reflected their hope, aspiration, and their life style through their design, the brilliant mix of colours which is admired all over the world. Bardhaman cluster is recognised as one of the heritage cluster of West Bengal among twenty renowned cluster all over the country and well known for Nakshipar Tangail saree and Jamdani saree weaving. Integrated Cluster Development Scheme has launched by Ministry of Textile in 2005-06, the main aim of this project is to make our age old traditional handloom industry globally competitive and protect this sector from the threats of power loom. Therefore this paper is concerned with the several features of Bardhaman cluster under Integrated Cluster Development Scheme and also make a SWOT analysis to highlight the strength and opportunities and recover the weakness and threat by innovative marketing strategies.
\end{abstract}

Keywords: Cluster, Master weavers, PWCS, ICDS, Handloom, Power Loom, SWOT.

Date of Submission: 13 January 2017

$\longrightarrow$ Date of Accepted: 27 January 2017

\section{INTRODUCTION}

Handloom industry is one of the important labour intensive industry and this industry mainly run by the rural artisan. So this industry has a great possibility to operate a profitable and productive way which can bring economic development in the rural India. So,it is clear that, it may be used as a powerful tool in the context of rural industrialisation of our country. None can deny it's many-folded solving ability. The study area of this paper, Bardhaman, is a growing center of handloom industry since 1942 from the time of Asahajog Andolan. A vast area of Bardhaman district (Katwa, Dhatrigram, Samudragarh, Tamaghata ) produce "Tangail Saree" and "Jamdani Saree" which can easily compete with any kind of power loom products by their beautiful craftsmanship, exclusive design, fine texture and attractive colour combination. Large number of weavers, master weavers, PWCS weavers, skilled designers, a good connection with State level Handloom Development Corporation "Tantusree" and "Tantuja" make this Bardhaman cluster one of the famous cluster in India.

\section{STUDY AREA}

Bardhaman district located south west part of West Bengal, the locational extent is $86.48{ }^{\circ} \mathrm{E}$ to $88.25{ }^{\circ} \mathrm{E}$ and $22.56{ }^{\circ} \mathrm{N}$ to $23.53^{\circ} \mathrm{N}$.It covers an area of 7024 sq.km. and total population of the district is 7723663 according to census 2011. The district consist of six subdivision in this district, they are Asansol, Durgapur, Kalna, Katwa, Bardhaman sadar south, Bardhaman sadar north. There are 32 police stations, 31 development blocks, 2 municipal corporations, 277 gram panchayats and 2438 villages in the district. Mainly two sub-divisions Katwa $\&$ Kalna have concentration of handloom weavers. There are about 94,000 (approx) people who were engaged in weaving either part or full time profession basis.

\section{OBJECTIVES OF THE STUDY}

This study is proposed to carry on with the following objectives:

- To evaluate the functions of Integrated Cluster Development Scheme in this particular cluster.

- To measure the progress of the cluster under this Integrated Cluster Development Scheme . 
- To analyse the working condition of small weaver, master weaver, private entrepreneurs based weavers of this cluster.

- $\quad$ To find out the threats and weakness of this cluster mainly which comes from power loom sector.

- To formulate some innovative strategies which can flourish the marketing system of Bardhaman cluster.

\section{DATABASE AND METHODOLOGY}

The paper is mainly deals with several secondary data. These secondary data has been collected from various offices and from E-sources. To enrich the study a number of articles, books on cotton textile industry were consulted. The related data of this paper mainly sourced by various Reports od Bardhaman cluster,District Census Handbook, Handloom development Office, Chinsurah and Katwa, B.D.O. etc. Then the relevant data and information have been organised, classified, tabulated, analysed by different statistical methods and represented though suitable cartographic techniques .

\section{A BRIEF BACKGROUND OF THE STUDY AREA}

The time of origin of cotton manufacturing industry in Bardhaman district is partly unknown because of scarcity of proper reliable data but according to Handloom development Office, Chinsurah and also other sources the Bardhaman cluster was mainly growing since 1942. The weaving work is mainly done by a particular weaving community called "Basak" community. These efficient weavers were migrated from "Nowakhali" and "Tangail" district (at present under Bangladesh) before partition of India and settled in Katwa, Dhatrigram, Samudragarh, Tamaghata area of Bardhaman district.

This renowned cluster of Bengal is full of small weavers, master weaver, PWCS weaver, individual private weavers, skilled designer, various technical person who make computerised card and also "National Awardee Weavers". Bardhaman cluster also very close to various state level apexes like "Tantusree" and "Tantuja" which can support and operate the marketing system of the cluster.

Though the main products of this cluster "Jamdani" and "Tangail" saree with Jacquard design but there are product variation from one block to another, they are as follows :

$>$ In Katwa- I and Katwa - II blocks, the main production is Gamcha, Lungi and 100s Tasar Tangail Saree with buti design.

$>$ Purbasthali I and Purbasthali II are the two blocks where concentration of weavers are highest, so these two blocks various product diversifications, such as- 100s Tangail Jamdani, Cotton Baluchori with Jacquard design, 100s Tangail Naksha par, Jamdani saree using Jacquard ,Gamcha, Lungi, Skarf, home furnishing materials etc.

$>$ The main product of Kalna block is 100s Tangail Saree with Jacquard.

$>$ Kethugram block of this cluster contain lowest number of weaver, Dhoti, Gamcha, Matha Sarees are mainly produced in this cluster. 


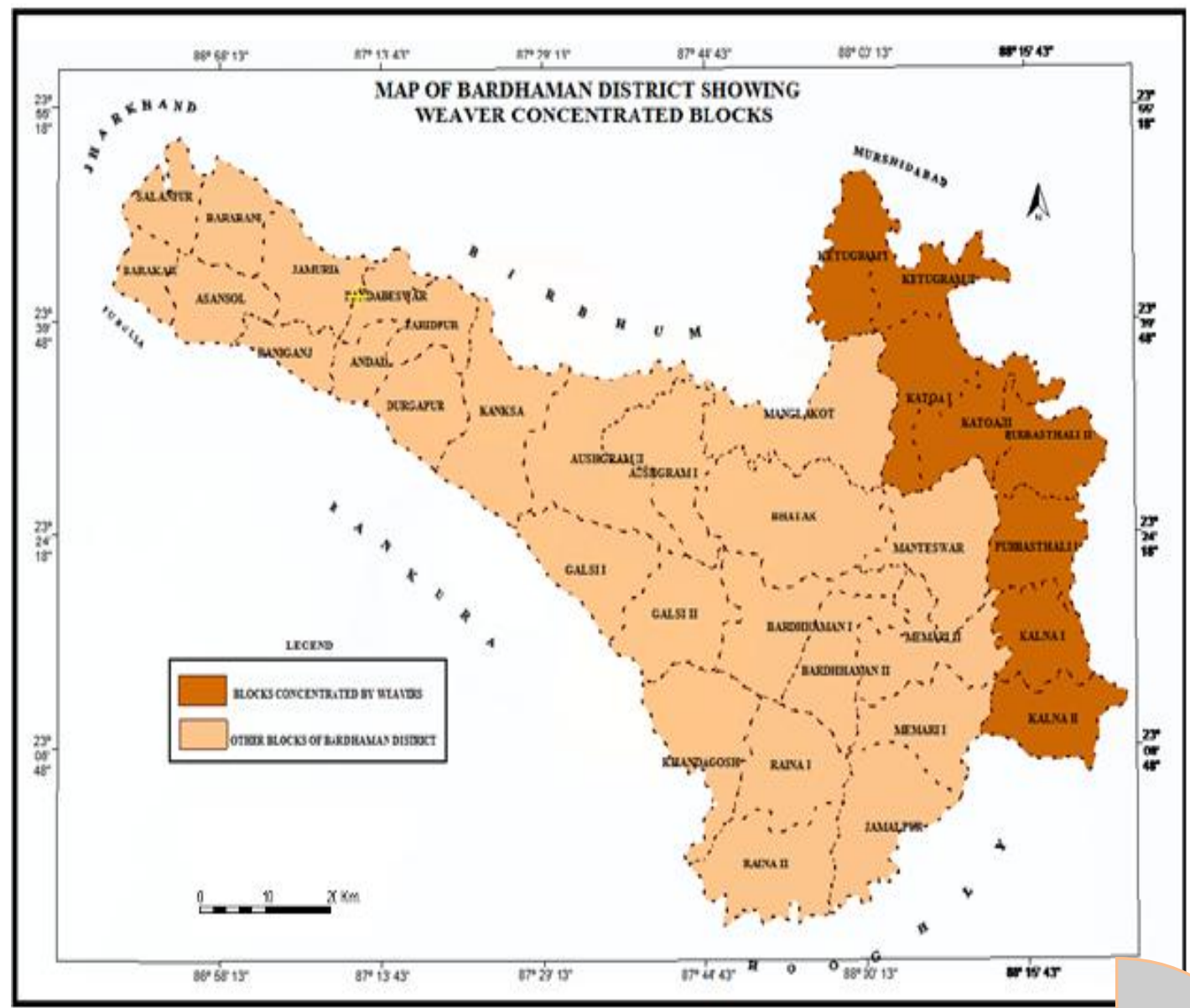

\begin{tabular}{|l|l|}
\hline NAME OF THE BLOCKS & NO. OF WEAVERS \\
\hline KATWA - I & $\mathbf{1 8 0 0}$ \\
\hline KATWA-II & $\mathbf{7 5 0}$ \\
\hline KETHUGRAM -I & $\mathbf{6 0 0}$ \\
\hline KETHUGRAM-II & $\mathbf{4 8 0}$ \\
\hline PURBASTHALI - I & $\mathbf{2 8 0 0}$ \\
\hline PURBATHALI - II & $\mathbf{5 5 0 0}$ \\
\hline KALNA - I & $\mathbf{4 0 0 0}$ \\
\hline KALNA - II & $\mathbf{3 5 0 0}$ \\
\hline
\end{tabular}

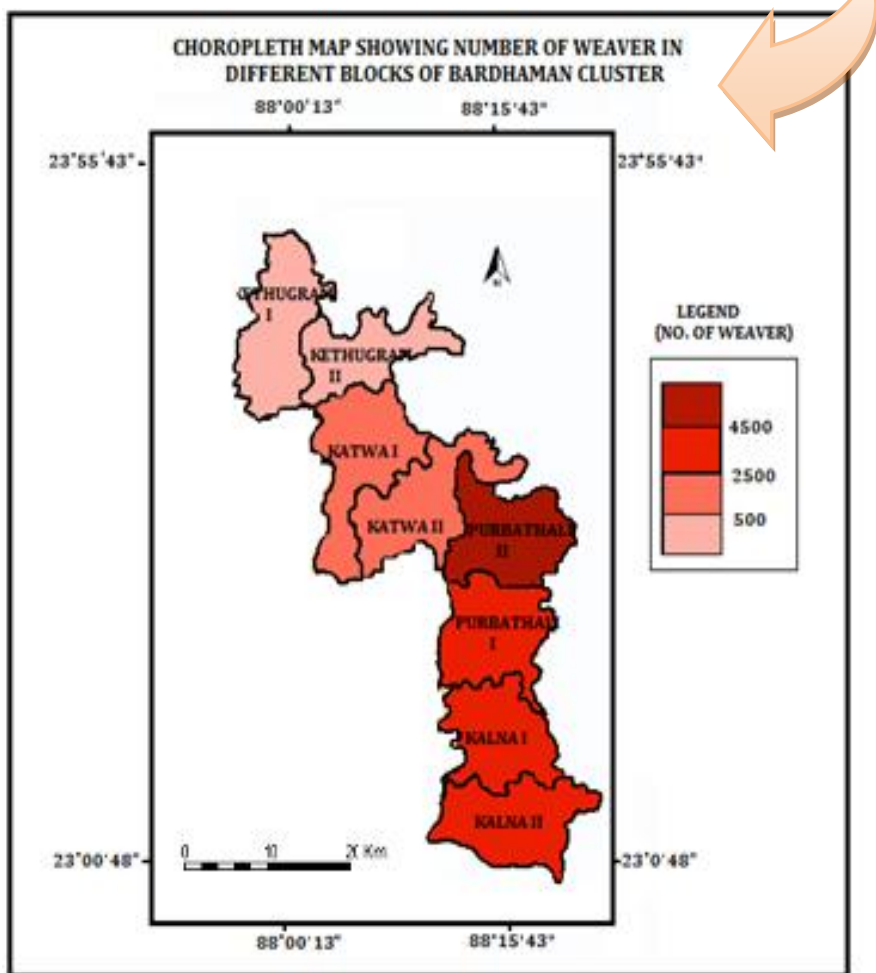

SOURCE: Handloom Development Office, Chinsurah. 


\section{HANDLOOM IN BENGAL}

West Bengal had a great heritage of cotton textile industry from the very ancient period of time. This work was traditionally done by rural artisans, they reflected their hope, aspiration, and their life style through their design , the brilliant mix of colours which is admired all over the world.

- Tangail sari weaving in Phulia (Nadia)

Santipur and Phulia are the two most glorious name in cotton handloom map of West Bengal. Extra fine Tangail sari, Jamdani sari with intricately embroidered, are produced from here. This handloom cluster is mainly dominated by co-operative societies. In the ever challenging market in handloom industry this two centres are able to make their own market by producing market driven design and make their feet strong in the industry.

\section{- Cotton sari weaving in Dhaniakhali (Hooghly)}

The cotton textile industry of Dhaniakhali was efficiently conducted by the rural artisans lived in the surrounding villages like- Somaspur, Harpur, Brindabanpur, Dhaniakhali, Talbona, Konan, Mahamaya,Mirjanagar etc. This was purely a cast based profession (Tantubay in Bengal).At the present time there are four working co-operatives namely- i) Somaspur Union Co-operative weavers Society Limited, ii) Dhaniakhali Unioin Tant Shilpi Smabay Samiti Limited, iii) Gurap Tant Samabay Samiti Limited, iv) Parambua Sahabazar Weavers Society Limited.

\section{- Silk Spinning and Weaving in Bahrampur-Murshidabad}

Murshidbad is famous for Moonga silk and Wild silk, this district, specially Behrampur is renowned for Khadi silk and raw silk weaving from cocoons. A number of people both men and women work in different separate sheds, silk weaving is mainly done by Muslim people of this area.

\section{- Jamdani sari weaving in Muragacha (Nadia)}

A small village Muragacha in Nadia district is very famous for Tangail weaving with Jamdani design, this heritage work is done by local muslim artisans.

\section{- Kantha embroidery in Shantiniketan (Birbhum)}

Santiniketan basically situated in a predominantly tribal belt which is one of the backward district of West Bengal, mostly known for Nobel Laureate Rabindranath Tagore as he spent his major part of life here and contributed a lot to make this backward region self sufficient. Among many other products of Santiniketan Katha Stich sector plays a very important role to rejuvenate the rural Bengal as this vibrant industry not only involved women worker but there are also some women who have started their own business with this sector.

\section{CONCEPT OF CLUSTER}

Integrated Handloom Cluster Development Scheme (IHCDS) is being implemented by the Development Commisioner for Handloom , Ministry of Textile, GOI, since year 2005-06. The main aim of this holistic approach is to make age old traditional handloom clusters of our country gobally competetive. To accept the ever challanging nature of this industry IHCDS also emphasise on identification of potential market and promotion of market driven designs, therefore, proper market assesment, indentification of modern trends, promotion of export, SWOT analysis are the most essencial approach of Integrated Handloom Cluster Development Scheme. The study area, Bardhaman cluster, is one of the most heritage cluster of West Bengal afer Shatipur-Phulia cluster, glowrily known for Tangail and Jamdani weaving, near about 94000 people are engaged in this cluster, so to make proper development of this cluster implementation of IHCDS is not enough, infrastructural facilities analysis like geographical location, various weaving equipments, value chain analysis are also important.

\section{DESCRIPTION OF BARDHAMAN CLUSTER}

Bardhaman cluster is one of the most glorious name in the Integrated Handloom Cluster Development Scheme, where about 94000 people are earning their livelihood through weaving variety product like Saree, Dhoti, Gamcha, Lungi and many other dress materials. Description of products:

- If special emphasis given on the type of products then two totally different product type can be found according to different location. The weaver who concentrated in Katwa Subdivision and migrated from Nawakhali district of Bangladesh are mainly weave handloom products like Lungi, Gamcha, Dhoti etc. But the weaver lives in Kalna Subdivision and sorroundings, they are expert in weaving with fine and quality 
handloom products like Tangail Saree, Nakshipar Saree, Buttik Saree with vibrant colour and modern design. These weaver are migrated from Tangail district of Bangladesh.

- The main products of this cluster are Tangail naksha par saree with Jacquard design, Matta Baluchori pain par with Buttik design, Tangail sari Matta par butik design, Silk Baluchori, 100s x 100s Dhakai Jamdani, Tangail silk x silk, Cotton Baluchori Saree, Baluchori Saree Silk x Cotton. Other product are Lungi, low quality handloom saree for daily use porpuse, Pere Dhoti, Kacha Dhoti etc. In Kalna subdivision some modern handloom products are also produced in small quantity, these are Stole, Dopatta, Home decorating materials, Dress materials etc. Recently the weavers of Shyambati, Tamaghata, Vidyanagar, Ghoshat, under Burdwan cluster also producing home furnishing, scarves, Nylon shirtings etc for export market.

- Jamdani and Tangail are the two premium product of this cluster in the heritage market of Bengal Handloom. The word Jamdani consist of two word, 'Jam', which means a 'Cup' and 'Dani' denotes 'Container'. This special product of Bengal considered as 'Textile of Excellence' because of its super fine quality and impressive design, this traditional saree conquered the hearts of different royal people during the region of Emperor Jahangir and Aurangjeb and the Mughal's recognised and acknowledge it's rarity.

- 'Nakshipar Tangail' and 'Silk Tangail' are another famous product of this cluster, this particular sari was originated at Tangail district of Bangladesh, previously it was known as 'Begum Bahar' where both silk wrap and cotton wrap were used to design the sari, the trend of tangail sari weaving in Bardhaman cluster has changed, mainly paper finished Jacquard designed Tangail sarees are woven at Samudragarhand Dhatrigram.

Description of Infrastructural facility:

- The main raw materials of this cluster are silk yarn and cotton hunk yarn in crossed reel form, these two type of yarn are largly supplied by NHDC Ltd. under 'Mill Gate Price Scheme' which has six depot in Bardhaman district and a small quantity of branded yarn supplied by yarn traders.

- Dying units of these cluster are mainly private in nature, so there is a lack of Govt. organised comprehensive dying section in Bardhaman cluster.

- If attention given on market of varius products mainly sarees of these cluster then a huge undulation can be found, because there are variety of saree according to quality, price and also terget market. Cotton based Tangail sarees are mainly used for daily domestic purpose so the market of these sarees are almost established but the sarees like Dhakai Jamdani, Silk Baluchori are higher in price and also there is no established or predicted market of this sarees.

- Share in export of Bardhaman cluster is very low till now but nine number of PWCS have been provided fund under Handloom Export Scheme.

Description of condition of weaver:

- In Bardhaman cluster, various types of weavers are found such as small or tiny weavers, Master weavers, Private or Individual weavers, PWCS weavers, skilled designer, technical person for making computeried cards, so from this point of view this weavers are the real strength of the cluster.

- Like the variety of sarees of this cluster the daily wages of the weaver changed from one location to another, a general weaver of Samudragarh or Dhatrigram get Rs.75-100 by weaving a cotton Tangail but the weavers of areas like Kamalnagar, Lakshmipur of Katwa subdivision get only Rs. 50 per day by weaving cotton Baluchori. So it can be easily said that Kalna Subdivision is more florished in nature than Katwa Subdivision.

- Though innovative technologies are adopted, weavers are giving their full effort to produce attractive designs but uncertainity inherent in the market and there is no alternative occupational opportunity for them except working in the agricultural field. So weavers are not satisfied.

- There are another crisis from the side of weavers, that weaving the yarn and making beautiful design on it generate pressure on eyesight which reduce the working efficiency of the weavers after 45 to 50 years old.

\section{SWOT ANALYSIS}

Bardhaman cluster is one of the renowned cluster among the 20 cluster of India and also a heritage centre of traditional handloom weaving after Shantipur and Phulia in West Bengal. Like any other cluster this cluster also has some strength and opportunitites as well as weakness and theats. So the main aim of SWOT analysis is to highlight the opportunities and strength and to take concern of the weakness and threats for betterment of the cluster. 
Strength :

- The main strength of this cluster is exclusive weaving efficiency in Jamdani and Tangail Sarees, though there are varities products produced in this cluster but these perticular two products reach the level of excellence because of it's unique design.

- The number of weaver in Bardhaman cluster is quite high (approximately 940000), so there is a healthy competetion among the weavers for better quality of production. So the there is ample scope for product diversification.

- In Bardhaman cluster the agglomeration of efficient weavers, co-operative societies, dyeing units and training centres make the accessibility of resource more easy.

- The cluster enriched with eight number of National Awardees weaver, super efficient weavers designers, number of supporting organisations like PWCS, NIFT, Textile Committee, National Handloom Development Corporation and Handloom Development office.

\section{Opportunities :}

- In recent time West Bengal government has taken special emphasis to reinforce the handloom industry of this state so this is high time to rejuvanate this age old haritage industry in terms of product diversifications, betterment of quality of products, making linkage with broder market and huge volume of buyers of the country as well as abroad by taking the facilities of E-Resource.

- Various handloom development schemes have been launched by central and state government which will bridge the gap between old and modern technology, such as modernisation of loom, dying unit, designs and infrastructural facilities also.

- Though this cluster is wellknown for Jamdani and Tangail Saree weaving but different other products like home furnishing materials, dress materials, lungi, gamcha, stole etc also can enrich the cluster.

- This cluster is very close to "Tantusree" and "Tantuja" which are state level apex of Handloom Development Corporation, so through this organisation the products of this cluster can be exhibited to different Handloom Fares of State as well as country or can open showroom in big cities of our country.

\section{Weakness:}

- Basic problem of regular availability of raw material is not major one but some areas like Kethugram, Kamalnagore are facing problem to cater their day to day requirement of small quantity of yarn. There is no good dye house or QDU in this cluster for which there is no control over quality as well as dyeing charges since dyeing work is done mainly from outside the district.

- If the value chain of this cluster be analysed, it can be found that actual craftmen are earning too small where as the outside traders gain large amount of profit with the same product because different values are added by the middle man. This cluster does not have such a marketing facility where weavers can sale their product directly to the buyers and can linked with huge volume of customer.

- Absence of alternative occupational opprtunity for the weavers is another drawback, as the working span of the weavers is generally 16 to 50 years old. Because after fiity years old most of the weavers suffer from problem related eyesight so they can not do the weaving work efficiently. To earn their livelihood they have to engaged themselves in agricultural field. Appart from this point of view, the working weavers also do agricultural work because of uncertainity of handloom market.

- The two main production of Bardhaman cluster i.e Jamdani and Tangail Saree, both are expensive in nature so this product can not be used by people of all strata.

- Due to lack of modernisation of loom and other infratructural facilities, the production cost still high in this cluster.

\section{Threat:}

- Demand of saree among the women has reduced today. At present the women specially the working women are more comfortable with salwar kamiz or different western outfits, so this current trend of dressing is surely a threat to the handloom weavers.

- Powerloom production is the biggest threat to the handloom industry, because it can produce low cost sarees with innovative designs and also in a large volume. So it is very obvious that market demand of powerloom production is quite high than handloom production.

\section{CONCLUSION}

Cotton handloom has its own demand because of the beautiful designs, quality, fine texture and attractive fret works of its products. There is no doubt that Bardhaman cluster is age old handloom cluster of Bengal as well as India and renouned for two most traditional handloom products Jamdani and Tangail. Though this cluster is 
second after Santipur cluster but the inherent threats of powerloom still belong in it. But the main strength of this cluster is its weaving efficiency and large number of weavers, so it can be assumed that they can cope with any kind of difficult situation. Central and State Govornment has implemented varoius schemes like Integrated Handloom Development Scheme, Hank Yarn Subsidy Scheme, marketing and design support, Health and life insurance scheme etc. to rejuvenated the glory of this industry. So it is the high time to use those schemes in a proper way and make innovative marketing strategy to link with greater volume of buyers which will ultimately develop the overall condition of the cluster.

\section{REFERENCES}

[1]. Chandrashekhar CP. Handloom: In Survival Mode, Paper presented in the seminar on „Growth and Prospects of the Handloom

[2]. Industry“e, Centre for Economic and Social Science Studies, Hyderabad 23rd-24th September, 20001.

[3]. Chattopadhayay Kamaladevi, ,The Glory of Indian Handicrafts ${ }^{\text {ee }}$, Clarion Books c.36 Connaught Place, New Delhi.

[4]. Dash S. „Handloom Industry in Indiaee, Mittal Publications, New Delhi, 1995.

[5]. Dev Mahendra S, Galab S, Reddy Prudhvikar P, Vinayan Soumya, ,, Economics of Handloom Weaving: a Field Study in Andhra

[6]. Pradesh ${ }^{\text {ee }}$, Economic \& Political Weekly, May 24, 2008.

[7]. Dutta Sutapa „, Problems and prospects of cotton industry in Dhaniakhali Block of Hooghly districte , The Journal of Indian SocialReview, June 2013, Volume I, Number II.

[8]. Kumar P. Surya, ,Handloom Industry in India: A Studye , International Journal of Multidisciplinary Research and Development.

[9]. Mahapatro PC. „Economics of Cotton Handloom Industry in India, Mittal Publication, New Delhi, 1986.

[10]. Mallik Swati, Poddar Sayanti, "A Review of the Handicraft Industry of Bolpur Subdivision of West Bengal with Special Referenceto the Social Well-being of the Associated Craftsmen"e, Geospectrum, April 2013.

[11]. Mitra Ashis, Choudhuri Prabir Kumar, Mukherjee Arup, „A Diagonistic report on cluster development programme of Shantipur

[12]. Handloom cluster, Nadia, West Bengal, Part -1, Evolution of cluster and cluster analysis", Indian Journal of Traditional Knowledge,Volume- 8(4), October 2009, pp.502-509.

[13]. National Handloom Development Corporation LTD., "Diagnostic Study of Bardhaman Handloom Cluster in West Bengal, Under IHCD Scheme".

[14]. Singh Kuldeep, Bansal Monica, , A Review of Handloom Export Units in India ${ }^{\text {ee }}$, National Monthly refereed Journal of Research in Commerce \& Management, Volome no. 1, Issue No. 11.

[15]. Venkataramma KS. „Handloom Industry in South India ${ }^{\text {ee }}$, The Dieceson Press. Madras, 1940. 